\title{
ŠKOCJANSKE JAME, SLOVENIA, IN 1891 - AN ALPINE CLUB EXCURSION
}

\section{ŠKOCJANSKE JAME LETA 1891 - IZLET PLANINSKEGA DRUŠTVA}

\author{
TREVOR R. SHAW ${ }^{1}$
}

${ }^{1}$ Karst Research Insititute, ZRC SAZU, Titov trg 2, SI-6230 Postojna, Slovenia, e-mail : izrk@zrc-sazu.si 


\section{Abstract}

UDC: 551.44(497.4)(091)

\section{Trevor R. Shaw : Škocjanske jame, Slovenia, in 1891 - an alpine club excursion}

The excursion after the 1891 general meeting of the Deutsche und Österreichische Alpenverein (DÖAV) was to their Section Küstenland in Trieste which was then actively exploring Škocjanske jame. J. Sigrist-Herder of Switzerland was one of those who visited the cave and he compiled an album containing contemporary publications and also 25 photographs by Francesco Benque of Trieste, 15 of which are published here for the first time. They show the 1891 festivities as well as scenes at the cave entrances and in the dolines. The visit is described here from newspaper articles by Sigrist-Herder supplemented by publications of the DÖAV. A comparison is made with a similar visit in 1885 when less of the cave had been explored. In 1891 the visitors were taken to Müllerjeva dvorana but a few people went along the walls as far as Dvorana planinskega društva, only discovered in 1887 .

Key words : cave, history, alpine clubs, photography, Slovenia, Škocjanske jame 1891, Francesco Benque, Sigrist-Herder.

\section{Izvleček}

UDK: 551.44(497.4)(091)

\section{Trevor R. Shaw : Škocjanske jame leta 1891 - izlet planinskega društva}

Po občnem zboru 1891 je Nemško-avstrijsko planinsko društvo (Deutsche und Österreichische Alpenverein - DÖAV) pripravilo obisk svoje Obalne sekcije (Section Küstenland) v Trstu, ki je takrat živahno raziskovalo Škocjanske jame. J. Sigrist-Herder iz Švice, ki je bil eden izmed obiskovalcev, je sestavil album fotorafij iz tedanjih publikacij, vključno 25 posnetkov Francesca Benque iz Trsta. 15 izmed teh slik je tu prvič objavljenih. Prikazujejo praznovanje leta 1891 in prizore iz jamskega vhoda ter iz dolin. Prispevek se opira na Sigrist-Herderjeve časopisne članke in na tiske DÖAV. Avtor primerja te dogodke s podobnim obiskom iz 1885, ko je bil raziskan šele manjši del jam. 1891 so obiskovalce peljali do Müllerjeve dvorane, nekaj pa jih je šlo dalje po stenah do Dvorane planinskega društva, odkrite šele 1887.

Ključne besede: jama, zgodovina, planinsko društvo, fotografija, Slovenija, Škocjanske jame 1891, Francesco Benque, Sigrist-Herder. 


\section{INTRODUCTION}

Each year the Annual General Meeting of the Deutsche und Österreichische Alpenverein (DÖAV) [German and Austrian Alpine Club] was followed by an excursion to somewhere within reach of the town in which it had been held. In 1885 the meeting had taken place in Villach and in 1891 it was in Graz. On both occasions the excursion was to the Club's Küstenland [Littoral] Section which was based in Trieste. In both years a visit was made to the caves of Škocjanske jame, which at that time were being energetically explored by the Section. The 1891 meeting and excursion were attended by J. Sigrist-Herder as the official delegate of the Schweizer Alpen-Club.

Sigrist-Herder, who was 41 years old, collected the guidebooks, photographs and other materials available at Škocjan and had them bound together in a special book with some additional information of his own.

This paper first describes the physical make-up of the book and its contents. Then the visit itself is described in some detail, using information from other sources as well as from the book itself. It is remarkable that some of the visitors were taken as far as the Alpenvereins-Dom [Dvorana planinskega društva], some $330 \mathrm{~m}$ beyond the present Hanke bridge, the furthest downstream that present-day tourists go. They used the narrow planks cantilevered out from the smooth vertical rock walls when the place was discovered in 1887. This fact was recorded by Sigrist-Herder himself in a newspaper article. A comparison is made between this 1891 excursion and the one made in 1885 .

Perhaps most important of all are the contemporary photographs taken by Francesco Benque in and before 1891. Nineteen of these are reproduced here; fifteen of them appear for the first time and others, published more than a hundred years ago, are here identified as Benque pictures. Three of them show activities during this visit.

\section{THE BOOK}

This book being unique, its physical make-up is described as well as its contents. The overall size is $330 \mathrm{~mm} \times 250 \mathrm{~mm}$ and $35 \mathrm{~mm}$ thick.

There are 16 leaves of thick card hinged with linen like those in some stamp albums, alternating with 18 unhinged leaves of thinner card - 34 in all. Most of the thicker leaves have photographs or engravings mounted on them while most of the thinner ones have pages of printed text pasted down on both sides. The pages of two other publications have not been laid down but are inserted before the blank leaves 27 and 29 .

This form of binding suggests that the book was bought as a ready-made album. But the original covers have been replaced by a specially designed binding in tan-coloured pigskin (Fig. 1). The back and the spine, both unlettered, are entirely of this material, while the front has been divided diagonally with one half covered in black calf skin. On the pigskin the words "Die Grotten Welt" and the decorative border are blind-stamped : on the black, both words and border are in gold. Mounted on the leather cover is a $42 \mathrm{~mm}$ diameter representation of the DÖAV badge, the edelweiss flower, made of a white metal with a brass centre. The binder was Ernst Hartung of Zürich, the city in which the Schweizer Alpen-Club Uto Section, to which Sigrist-Herder belonged, was based.

The title page (Fig. 2) was designed and made by Sigrist himself (from now on, the shortened 


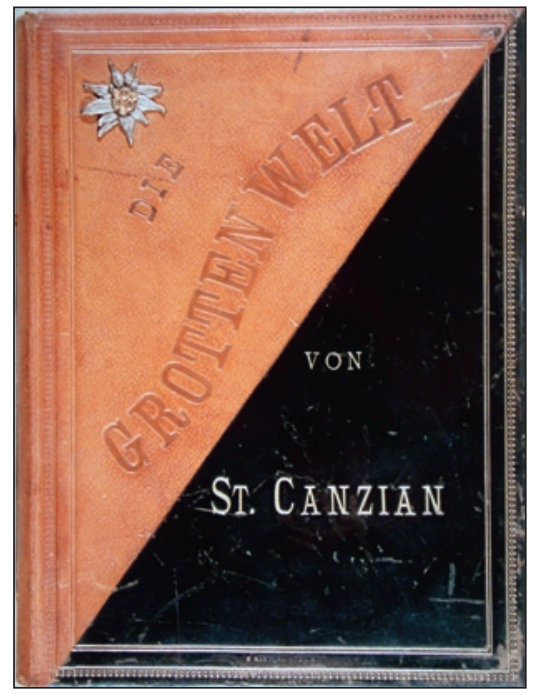

Fig. 1: The front cover of Sigrist-Herder's album, $33 \mathrm{~cm}$ high, with the metal edelweiss symbol of the Deutsche und Österreichische Alpenverein mounted on it.

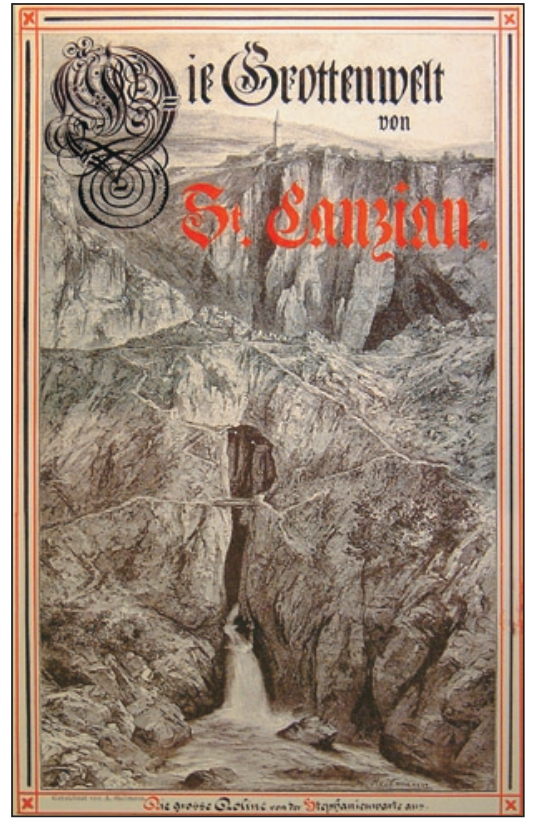

Fig. 2: The title page, lettered and ruled by Sigrist-Herder on a printed drawing of the Škocjan dolines by Heilmann. form of his name will be used). As will be seen later, he was a skilled calligrapher. Not only this page but also the individual pictures are titled in black and red with frames ruled in red (sometimes with white or black as well) and the pasted pages of text are given red and black ruled frames.

The source of the picture used as the basis of this title page is a mystery. Although reproduced from a drawing by Anton Paul Heilmann (1830-1912) who made many of the illustrations used in the DÖAV Zeitschrift (including the one reproduced here as Fig. $3)$, no other copy has been traced. Its relatively large size $(262 \times 158 \mathrm{~mm})$ is unusual too and suggests that the picture may have been published just as a separate print. Strangely, this picture was later redrawn in his own style by Lucien Rudaux, an artist who contributed to some of Martel's books, and was published in the annual report of the Küstenland Section (Rudaux 1910).

Apart from the picture titles, Sigrist's writing appears in a poem (to be mentioned later) on f.24 and in two signed inscriptions. On the otherwise blank f.1 (Fig. 4) his signature and affiliation are dated 18 May 1892, presumably the date when the volume was completed.

Three printed publications and a series of newspaper articles have been inserted in the book.

The text pages of Friedrich Müller's (1887) 111page guidebook to Škocjanske jame, published by the Küstenland Section of the DÖAV, are mounted on alternate leaves (the ones of thin card) from f.3 to f.25, while two of its illustrations appear on the backs of ff.6 and 24. It will be noted that, in order to have all the text visible although pasted down, he must have obtained two copies of the book.

Only part of Müller's (1890) major paper in the DÖAV Zeitschrift (pp. 236-251, concerned with Tominčeva jama) are included in this volume, placed together between ff.26 and 27, but in addition six of the illustrations from the rest of the paper have been used, including the one reproduced here as Fig. 3.

The third publication, incorporated in the book before f.29, is a pamphlet of 30 small pages numbered [3]-32 but without a title page. Sigrist has labelled it 


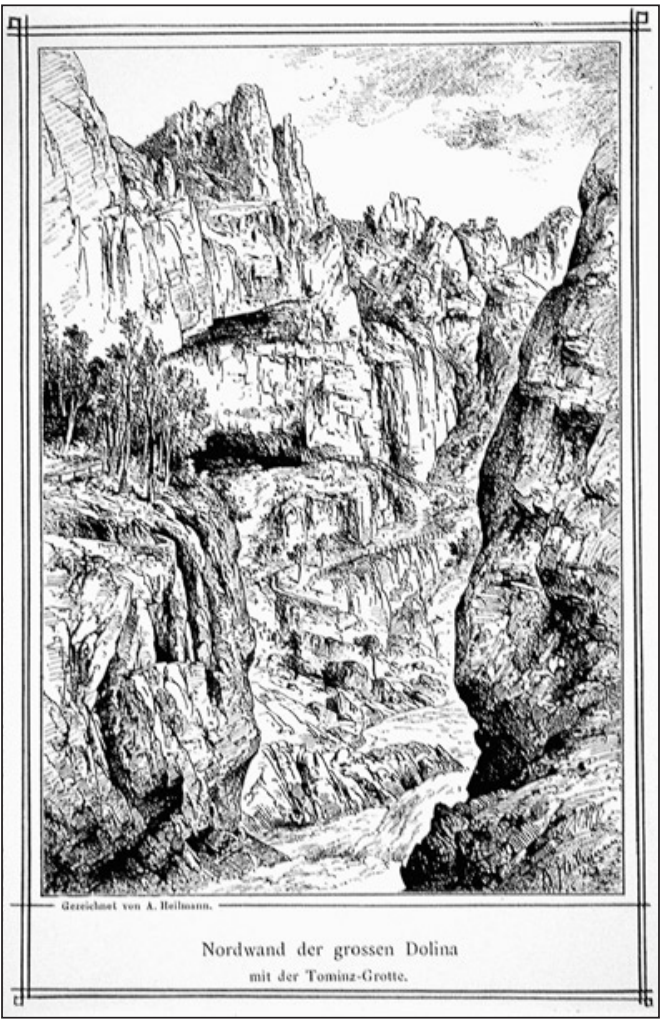

Fig. 3: Velika dolina with Tominčeva jama as drawn by Heilmann (Müller 1890, opp. 195) and pasted down on $f .22$ of the album. The railed pathways shown include the one leading towards the river, used as access to Schmidlova dvorana until 1888.

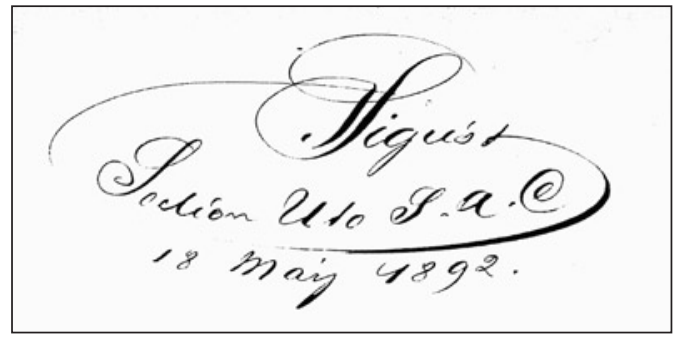

Fig. 4: Sigrist-Herder's signature on f.1, showing that he belonged to the Uto (Zürich) Section of the Schweizer Alpen-Club.
"Neue Fahrten in die Grottenwelt. von F. Müller. 1890." - a title which appears in no bibliography. Eventually it was identified as an unrecorded separatum of a paper of different title (Müller 1891) which appeared in three parts in successive issues of the DÖAV Mittheilungen. This has large pages printed in two columns but the text is identical. The separatum present here omits only the plan and section by Hanke showing the new discoveries made between 26 July and 5 October 1890.

Tipped in near the end of the volume (ff.31-33) is a series of three articles ( $\mathrm{Si}$ grist-Herder 1891) now identified as from a Swiss newspaper. Parts 1 and 2 consist mostly of a short history of Škocjanske jame summarised from Müller (1887) with a few errors introduced (e.g. 1802 given as the date of Cassas's visit, which took pace in 1782, instead of as the publication date of his book). Extracts describing activities during the 1891 visit are used and quoted later in this paper.

Also tipped in towards the end of the volume are two plans and sections (Figs. $5 \& 6$ ). One (on f.28) records Hanke's explorations in Kačna jame on 28 June 1891, the very day he suffered a heart attack at the cave which eventually led to his death on 3 December. The other (f.30), dated 15 March 1891, shows Mušja jama (Jama na Prevali 2) in detail. These two surveys appear not to have been regularly published in this form, each being printed on one side of a large piece of poor quality paper, so they are reproduced here. Neither of these relate to the DÖAV excursion, except that they were obtained then, so they are not mentioned further.

The very important series of 25 photographs by Francesco Benque in the book are discussed in detail later. Three of 


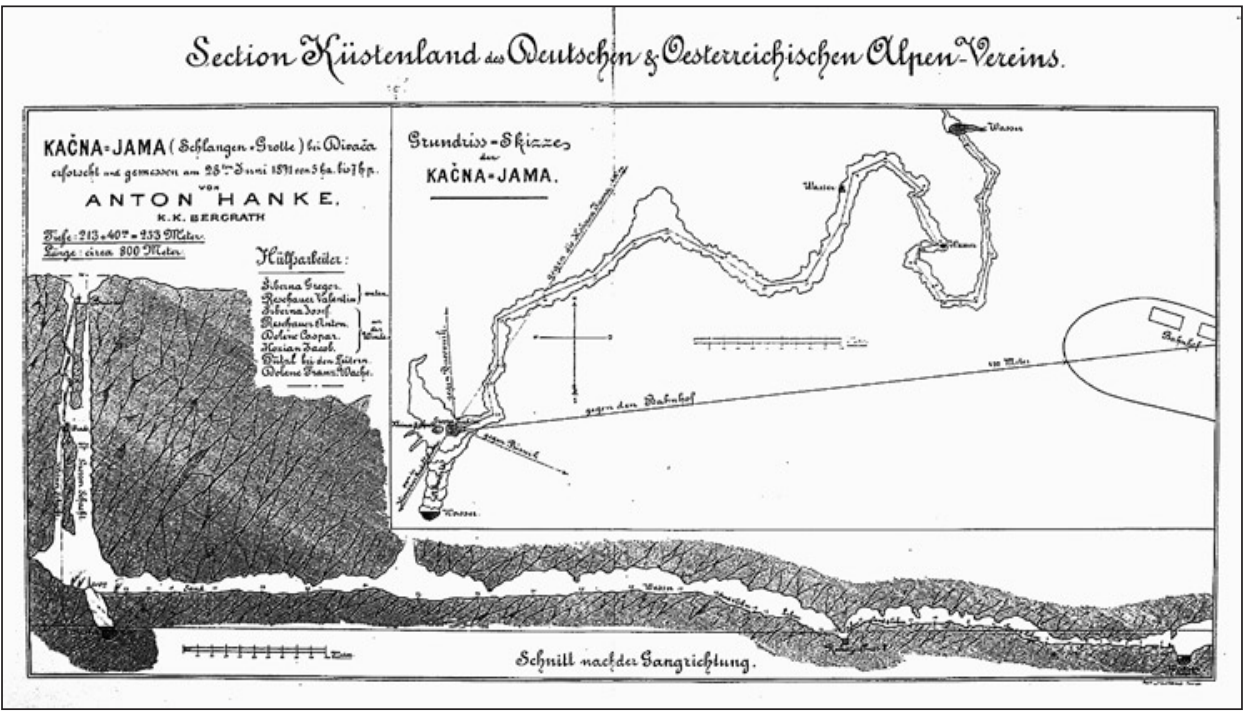

Fig. 5: A printed survey of Kačna jama showing Hanke's discoveries of 1891, apparently never published in this form, tipped in on f.28. Size of original $267 \times 443 \mathrm{~mm}$.

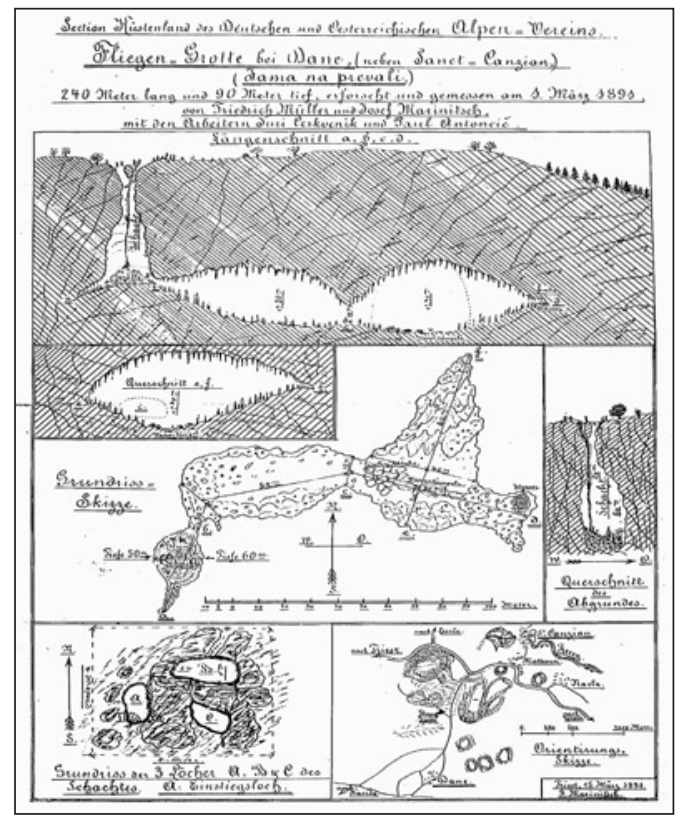

Fig. 6: A printed survey of Mušja jama near Matavun, apparently never published in this form, tipped in on f.30. Size of original $444 \mathrm{~mm} \times 293 \mathrm{~mm}$. them show activities during the excursion visit on 9 August; 16 others also were not previously known to exist; and other copies of the remaining six are among the 23 in the collections of either the Museo Civico di Storia ed Arte di Trieste or Maurizio Radacich of Trieste. These 23 have all been reproduced by Radacich (2002). Of the others, 15 are printed here for what is believed to be the first time, together with another four that have not previously been credited to Benque. One of the photographs in Radacich $(2002,24)$ which occurs in this album too is also printed here, as Fig. 30 , because it is discussed in the text. In addition the album contains photographic copies, later issued as postcards, of four paintings. Janko Gombač of Matavun has very kindly allowed us to reproduce another most interesting Benque photograph (Fig. 32) which he possesses.

In due course this book will belong to the Karst Research Institute at Postojna. 


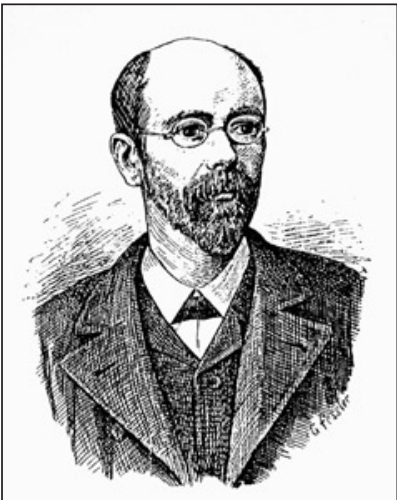

Fig. 7: Friedrich Müller (18421919) (Pazze 1893, opp. [353]).

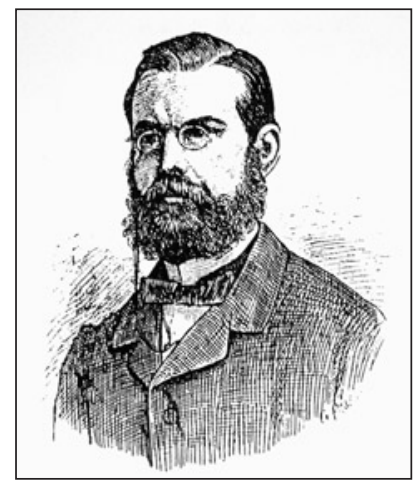

Fig. 8: Josef Marinitsch (18381915) (Pazze 1893, opp. [353]).

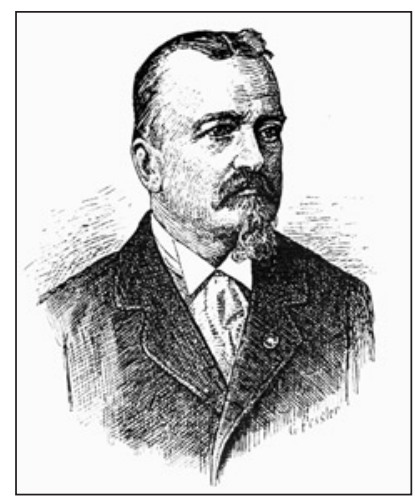

Fig. 9: Peter August Pazze (1829 or 1830-1893) (Pazze 1893, opp. title page).

\section{SIGRIST-HERDER}

The newspaper articles (Sigrist-Herder 1891) are signed "Sigrist" and his signature in the book (Fig.4) is just "Sigrist" also. But the record of the Annual General Meeting (Anon. 1891, 237) and Globočnik-Sorodolski (1891) both refer to him as Herr Sigrist Herder as if his surname (family name) were Herder. The first attempts to identify him were confused by this and no records were found in the archives of the Schweizer Alpen-Club for anyone called Herder (Debrunner 2002). Subsequent investigation, involoving a page-by-page search of both the Club's Jahrbuch and its Mittheilungen over a period of 20 years, finally revealed an obituary (Anon. 1910) for a "J. Sigrist-Herder" (with hyphen) who is clearly the man concerned. Further information was obtained from the Davos archives, by René Scherrer (2005) of the Schweizer Alpen-Club. No portrait has been found.

Jakob Sigrist-Herder was born on 1 May 1850 and died at Davos on 1 March 1910 "because of over-exertion during a skiing tour". In the Section Uto of the Schweizer AlpenClub, to which he belonged in Zürich, he was known also as "Uto-Köbi" (perhaps from Kobold, a goblin?) and a poem about a club celebration (Sigrist-Herder 1893) was published under that name. His ability as a calligrapher "capable of producing diplomas and other documents" has already been seen in Fig. 2. The obituary notes also his sense of fun and the humorous verse and pictures that he produced. He moved from Zürich to Davos about1895 and became increasingly interested in photography.

\section{THE DÖAV EXCURSION TO TRIESTE AND ŠKOCJAN}

The $18^{\text {th }}$ Annual General Meeting of the Deutsche und Österreichische Alpenverein was held in Graz on 5 August 1891. "Herr Sigrist Herder"(no hyphen) was recorded as the official delegate of the Schweizer Alpen-Club (Anon. 1891, 237). From the Küstenland Section came Friedrich Müller (Balázs 1992, 127) (Fig. 7), Josef Marinitsch (Müller 1916) (Fig. 8), Dr Franz Swida and two others (Pazze 1893, 331). Peter August Pazze (Anon. 1904) (Fig. 9) himself remained at home in the Küstenland, no doubt to finalize arrangements for the excursion there. Anton Hanke (1840-1891) was already ill after the heart attack at Kačna jama on 28 June which was 
to cause his death only a few months later.

The DÖAV excursion arranged to take place after the meeting was to the Section Küstenland, based in Trieste, whose interests lay in what is now south-western Slovenia including Snežnik and the Karst. There are three main sources of information about the excursion, which included a day at Škocjanske jame. Pazze's (1893, 315-319) history of the Section Küstenland gives the most accessible account though, confusingly, it appears as if it occurred in 1890 due to the omission of the 1891 year heading in the book. It is supplemented by an article in the DÖAV Mittheilungen (Globočnik-Sorodolski 1891) and by Sigrist-Herder's (1891) own newspaper articles. The latter provide the most detailed account of the cave visit itself.

The sources disagree about the total number of people coming on the excursion. Pazze (1893, 315) has "more than 400 expected festival guests arrived" at Trieste on Friday 7 August. GlobočnikSorodolski (1891) says that nearly two hundred went from Graz to Trieste on that day, while another hundred had travelled the day before so that they could see Ljubljana and Postojna on the way. The latter seems to agree with Sigrist-Herder's (1891) statement that 300 participants travelled from Trieste to Divača for the cave on 9 August. But for that journey a figure of 700 is given both by Globočnik-Sorodolski (1891) and by Pazze $(1893,317)$ who say that the 700 were made up of "our guests together with members of the Section Küstenland itself and also a great many invited guests and their ladies".

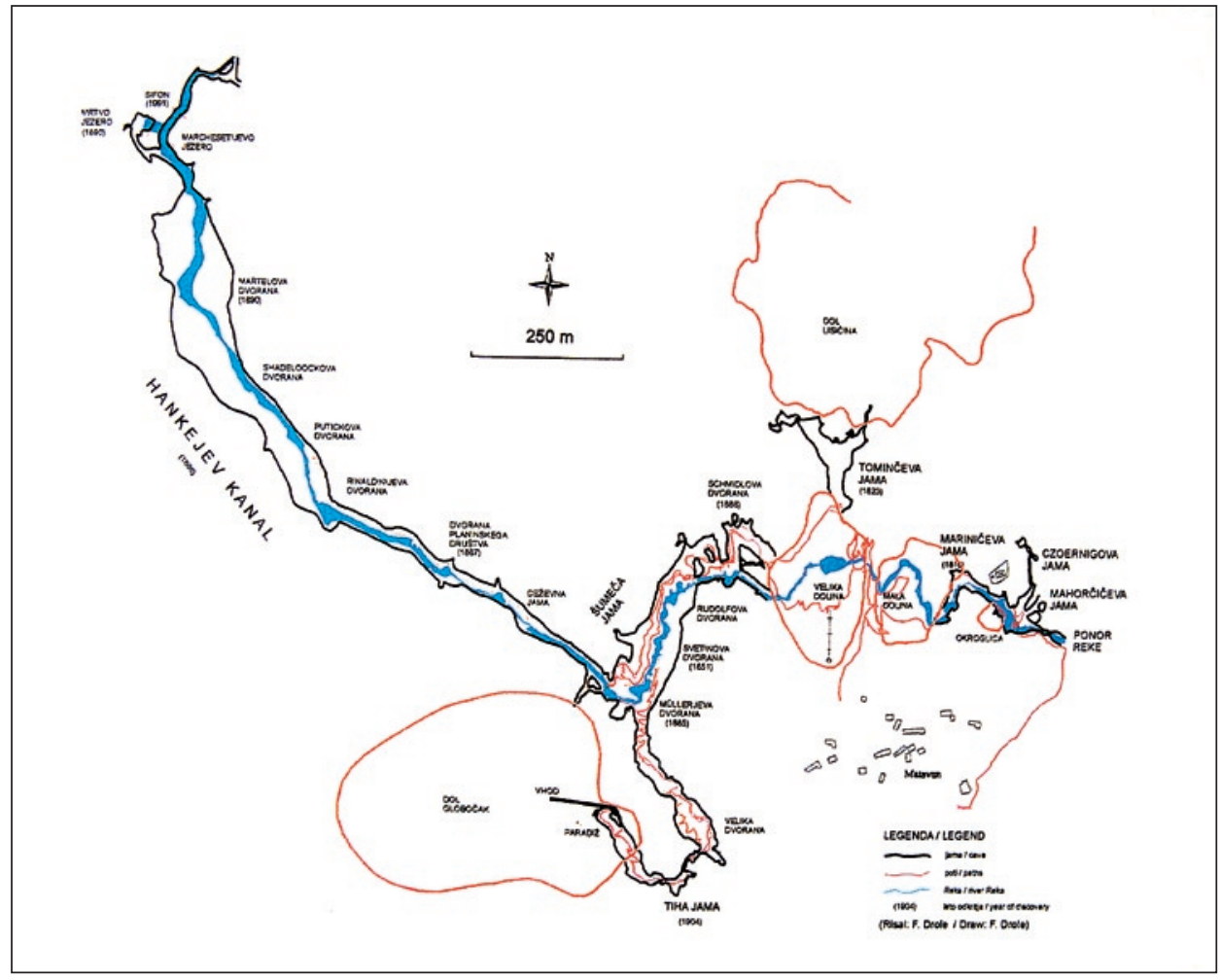

Fig. 10: A simplified plan of Škocjanske jame (surveyed \& drawn by Franjo Drole). 


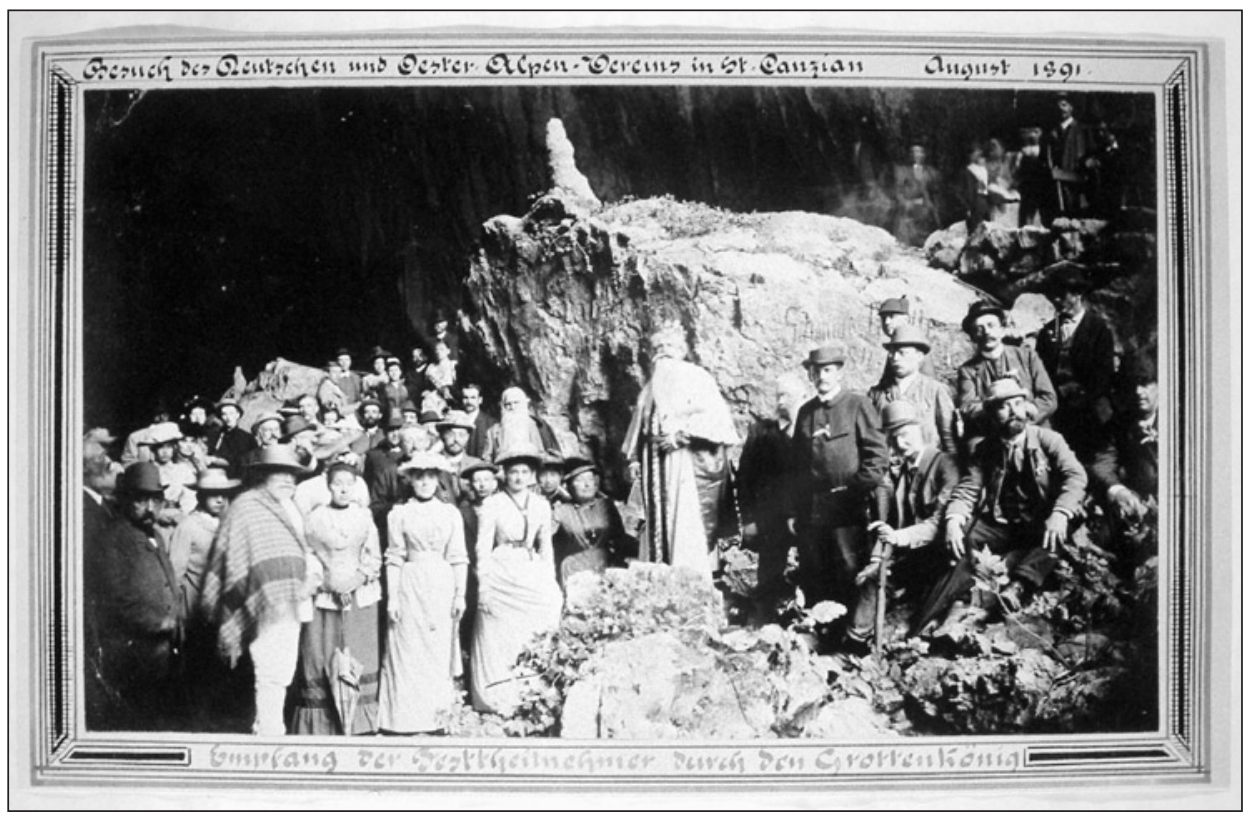

Fig. 11: Some of the party with the Enzian King in the entrance of Schmidlova dvorana on 9 August 1891 (phot. Benque), from f.24 of the album.

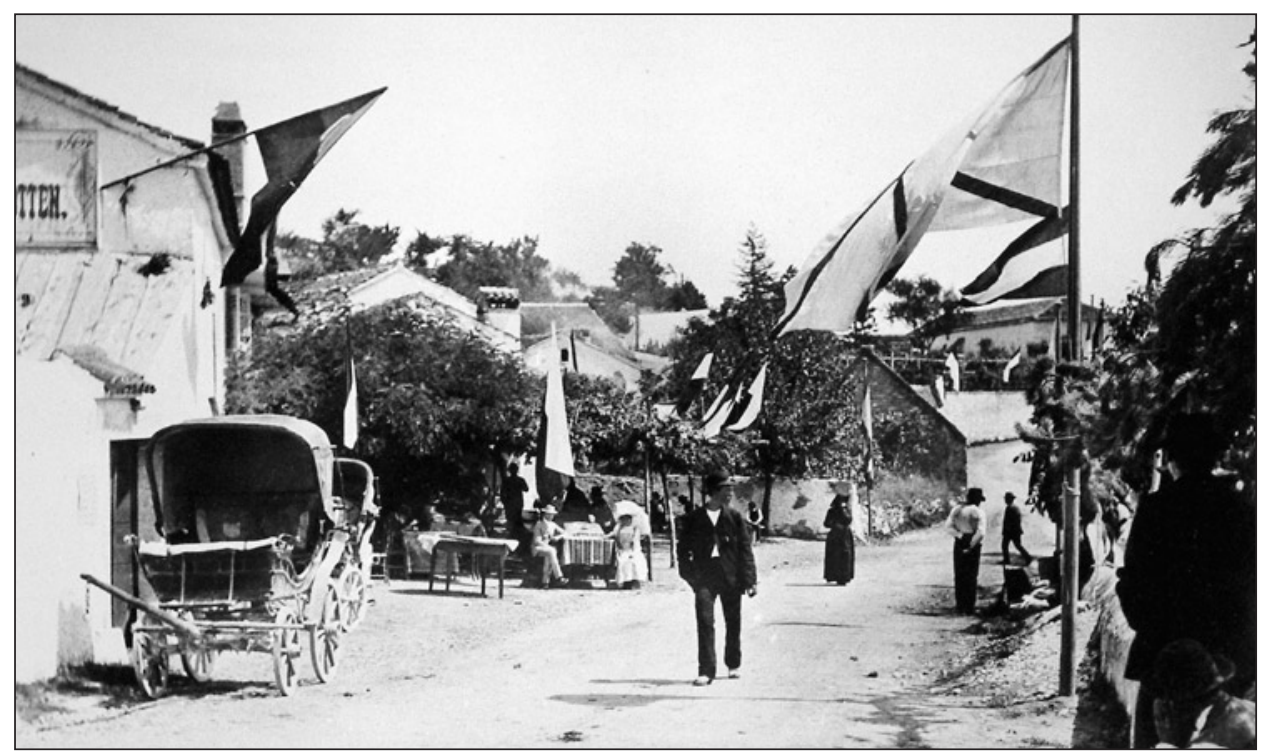

Fig. 12: Tables outside the Gombač inn, which is part of the building on the left, photographed by Benque a little before midday on 9 August 1891. Most of the visitors were in the cave at that time. From f.22v of the album. 


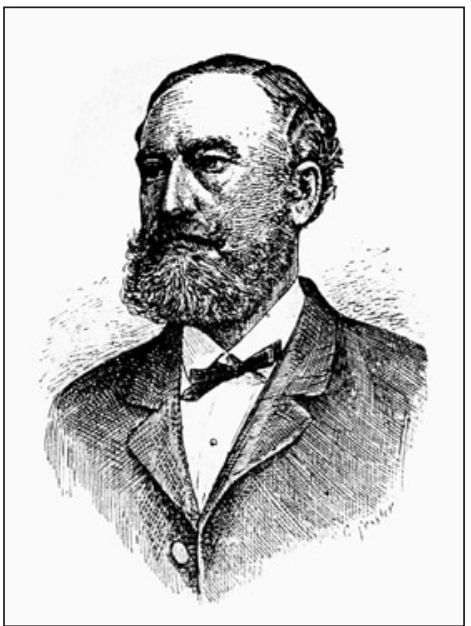

Fig. 13: Baron Carl Czoernig (fl. 1878-1893) (Pazze 1893, opp. title page).
To avoid undue references in brackets, from now on the account can be taken as compiled from all three sources cited.

Back now to the visitors' arrival at Trieste on 7 August. It was raining heavily so the planned garden party in the grounds of the Austrian Association was cancelled and everyone met in the great hall of the Association where Pazze, as head of the Küstenland Section, made a speech and a male voice quartet sang folk songs.

The next day was dry and was spent in or near Trieste. Some visited the castle at Miramare, but the majority preferred to see the new port facilities with the sailing ships and steamers alongside. A four-hour cruise round the Gulf stated at 1600, going as far as Piran and Duino. The garden party that had been rained off on the previous day was finally held at the Austrian Association and culminated in a firework display.

On Sunday 9 August, the day of the cave visit, the party of 700 (or 300) caught two special trains from S. Andrea station in Trieste to Divača where they arrived at 1000 . From there the local band led the party as they walked, via Dolnje Ležeče, to Matavun - a journey that took $3 / 4$ hour.

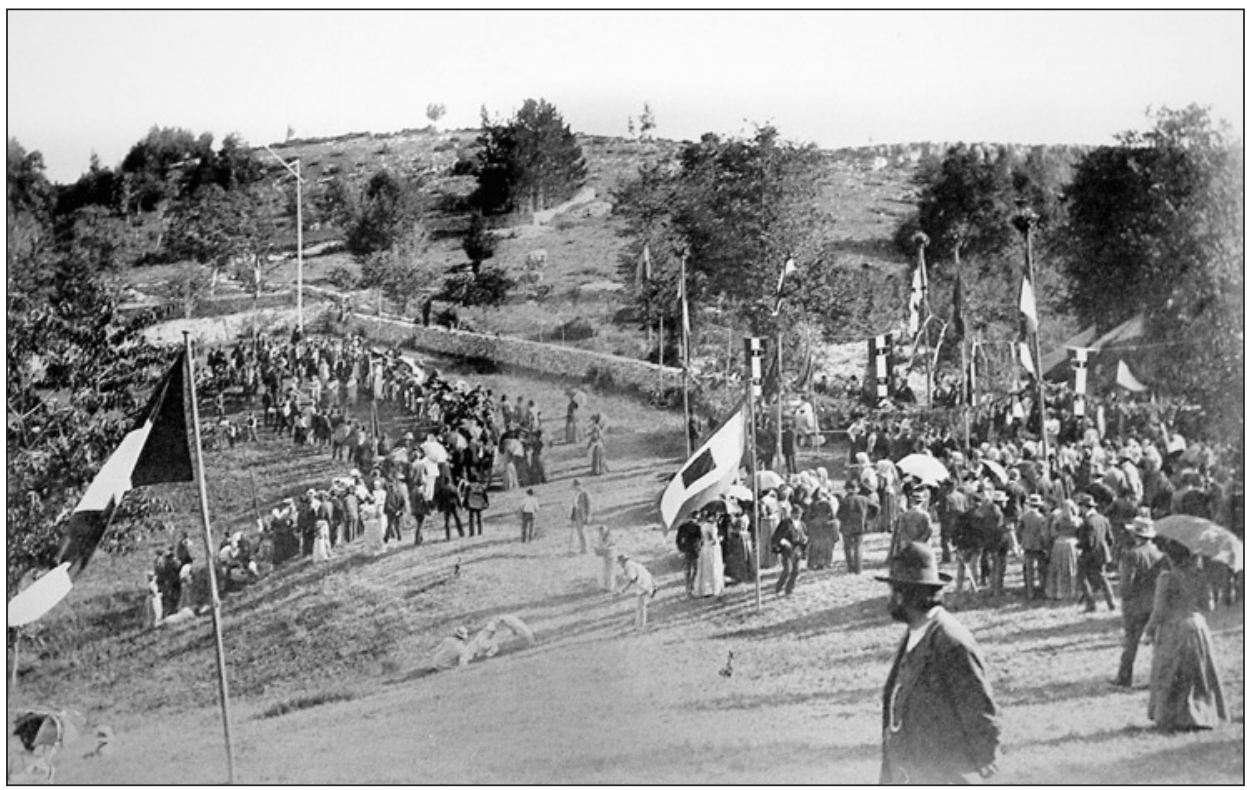

Fig. 14: Some of the afternoon activities in the field opposite the inn on 9 August 1891 (phot. Benque), from $f .22 v$ of the album. 
There were flags and at least one triumphal arch "with a great eidelweiss on it" on the way. They stopped at the Gombač inn for what must have been a very small snack, for at 1100 they set off for the cave as described in the next section.

\section{ŠKOCJANSKE JAME AND MATAVUN}

Even before reaching Matavun the party had passed at the viewpoint above Velika dolina, then called Stephanie Warte after the Crown Princess. Guided by Pazze and Müller, they walked from the inn towards the Natural Bridge (Naravni most) and turned right, down into Mala dolina where they saw Brihta jama; then through the artificial tunnel beneath Naravni most, across Miklov skedenj, the Tommasini bridge and down to the Oblasserwarte, the low level viewpoint close to the waterfall beneath Naravni most. By now in Velika dolina, they followed the path to Tominčeva jama (Fig. 3) and then by the 1888 path, the Plenkersteig (Fig. 33), to Schmidlova dvorana, the normal way into the main cave at that time.

At Schmidlova dvorana (Fig.10) one of the Section members, Hermann Sadée, dressed as the Enzian King or Grotten König with a long flowing beard, a purple cloak and a crown, came out from the darkness, "a cave ghost", and greeted them with a special poem. A band also played and a drink [?slivovka, or maybe beer as in 1885] was provided. Fig. 11 shows the Grotten König in his robes with some of the visitors around him. The great boulder, which carried the inscription dated 1884

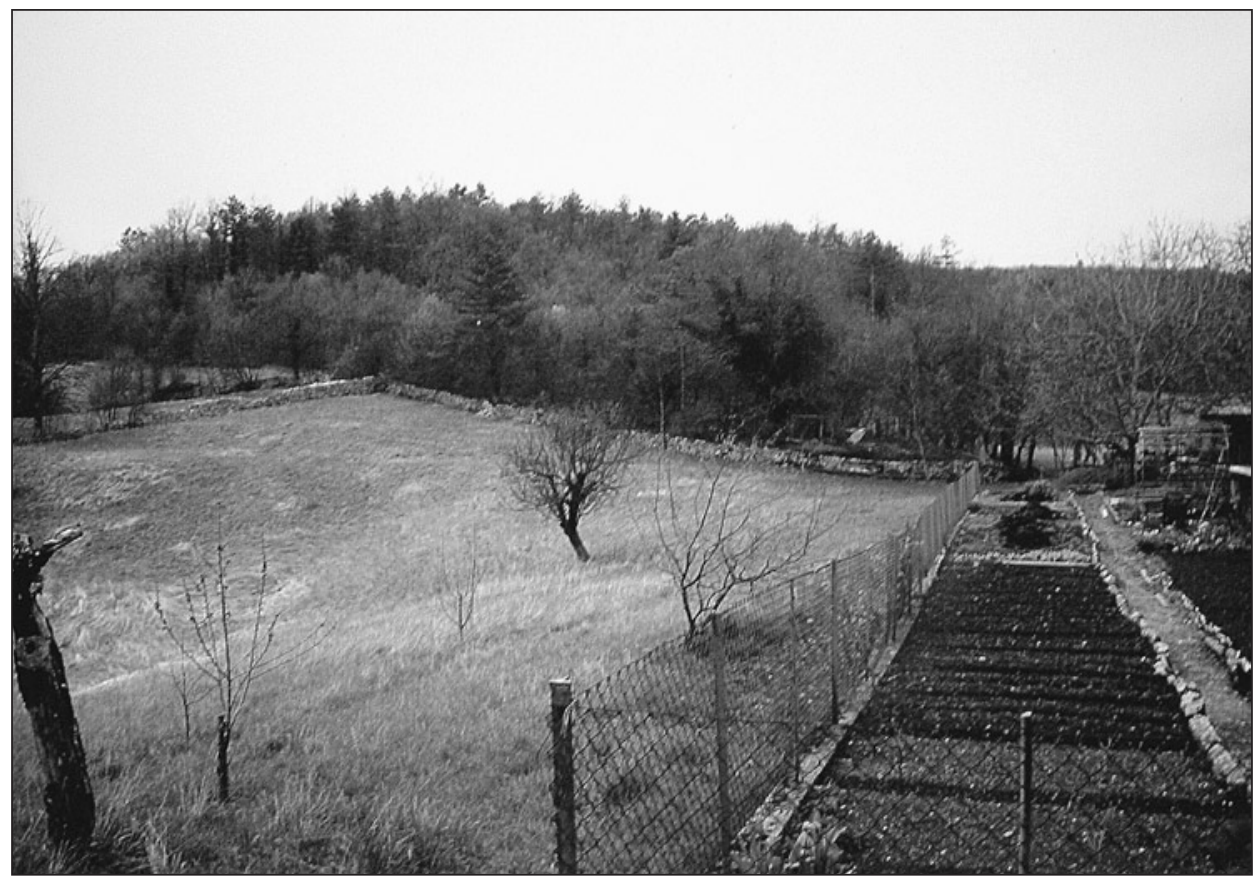

Fig. 15: The same scene on 14 April 2002 showing the greatly increased forest cover (phot. Borut Peric). 
(hidden here by people) when the Section started its explorations (Pazze 1893, 359) was removed later when the floor was levelled.

The enzian itself is the mountain flower the gentian. The mountain sprite the Enzian King is not part of Slovene folklore but of Germanic Austrian origin. Austrian mountain herdsmen used, at the end of the season each year, to elect a "king" or "queen" of the herdspeople. It may have been from that that some Austrian climbing clubs adopted this mountain flower and mountain custom as their own. The DÖAV itself, however, has the edelweiss (not the Enzian) as its symbol as on the book's cover (Fig. 1) and on the triumphal arch passed by the excursionists. Within the DÖAV, it was the Section Küstenland that had the Enzian as its symbol. Their humorous social newsletter, published from 1873, was called Enzian, and the Enzian King had ceremonial duties on occasions such as the opening of mountain huts or special visits like this one in 1891.

Sigrist has called the Enzian King the Grotten König, as an appropriate title in the cave activities of a mountain club. The ten-verse poem of welcome spoken by him has been written by Sigrist in the book (f.24) but it does not merit printing here.

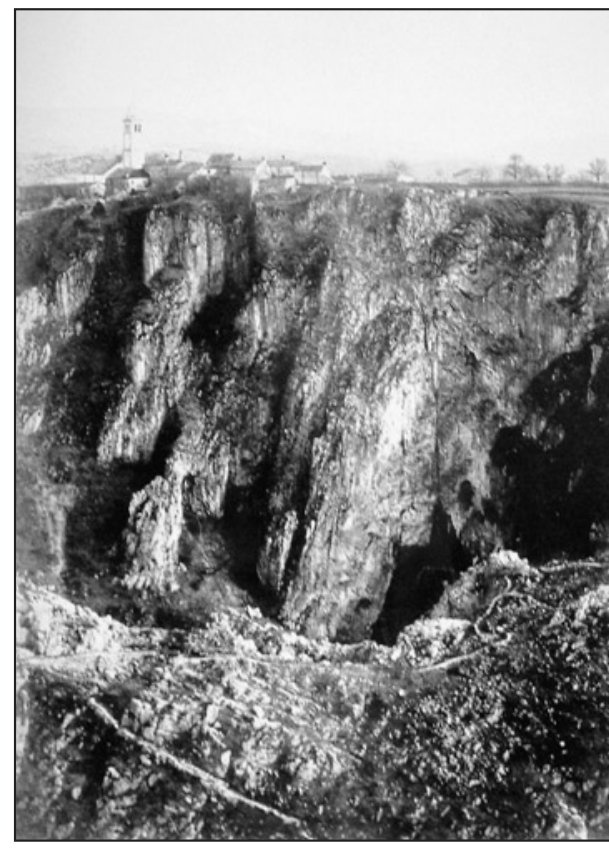

Fig. 16: Škocjan village above Mala dolina, with Naravni most (the natural bridge) separating the latter from Velika dolina in the foreground. The written title of this picture on $f .4$ draws attention to the "new cave path" on the top of the bridge. That was the Alpenvereinsweg, made by the DÖAV in 1884. (phot. Benque).

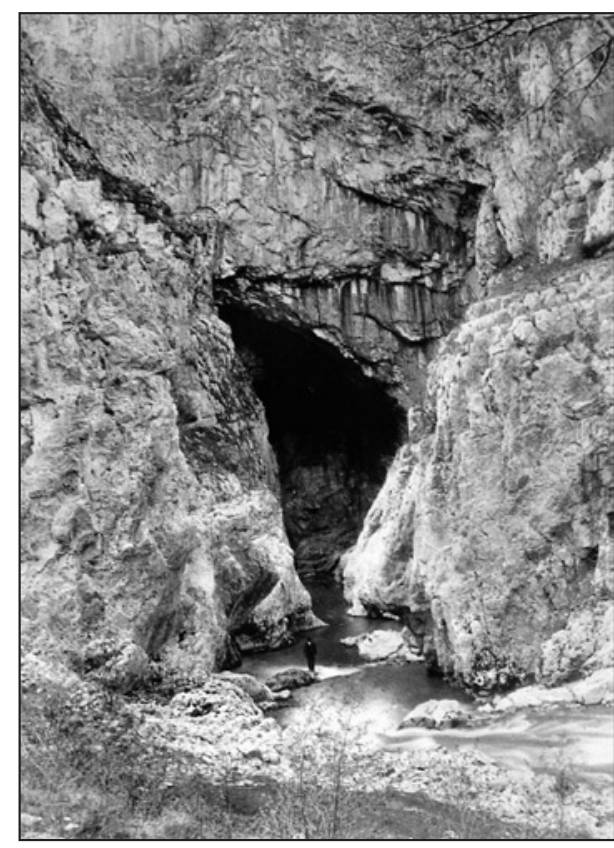

Fig. 17: The Reka sinking for the first time, at Mahorčičeva jama. The present high level bridge and path at the entrance were not built until 1933 (Puc 1998, 79). (phot. Benque on f.16v). 
The party now went further into the cave and Sigrist takes up the story:

Slowly we advanced to Rudolfova dvorana that had been prepared with hundreds of coloured [candle] glasses. Such glasses were also suspended on wires like pearl necklaces from the $70 \mathrm{~m}$ high ceiling to the rushing river, making the waterfalls shine in colours. It was a wonderful spectacle, unique. Suddenly a mighty rocket rises from below, its fiery balls illuminating the fantastic forms of the speleothems, crashing against the rocks, disintegrating or dying in the waves. As the group moves on, blinding magnesium flares make the space like daylight. With slow and careful steps the party goes forward to the $20 \mathrm{~m}$ high Cili-Cap [a boat-shaped promontory] and from there over the Teufelsbrücke [a former bridge] into the long Svetinova dvorana. In every tiny space coloured glasses containing candles were placed. A lot of money must have been spent on these illuminations. (Sigrist-Herder 1891)

It is evident that at this stage Sigrist was nowhere near the front of the party, for he had not even reached Müllerjeva dvorana (Fig. 10) when:

Suddenly the long line of people stopped, shrill horns sounded and the guides shouted "everyone back". Many people looked worried but the first visitors had simply come to the end of the path which is so narrow that people could not pass each other; also the candles were burning rapidly in the windy conditions. How sad it would be not to see the most interesting part, the Müllerdom.

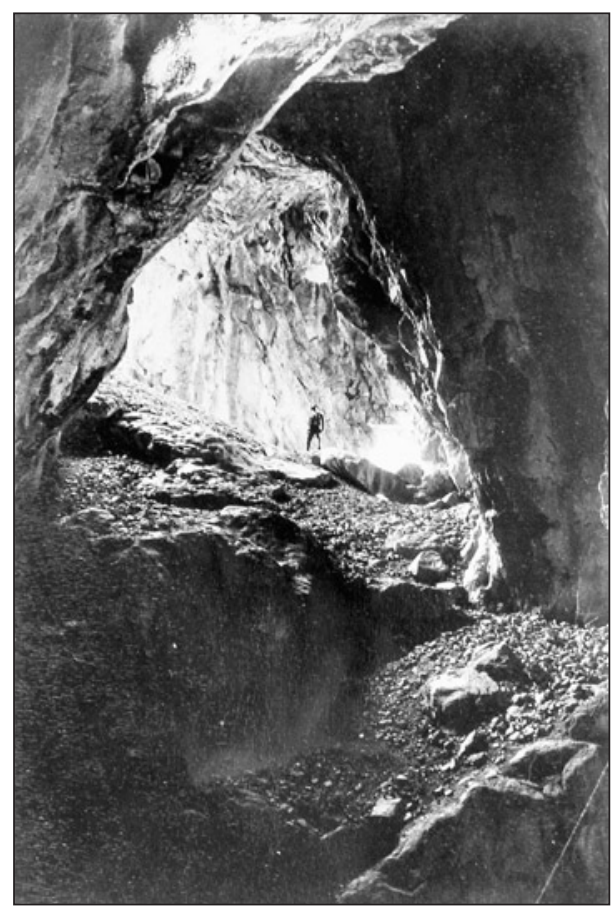

Fig. 18: Looking up towards the Okno in Mahorčičeva jama. Labelled in ink on f.16v as the entrance, which it was until 1933 (phot. Benque).

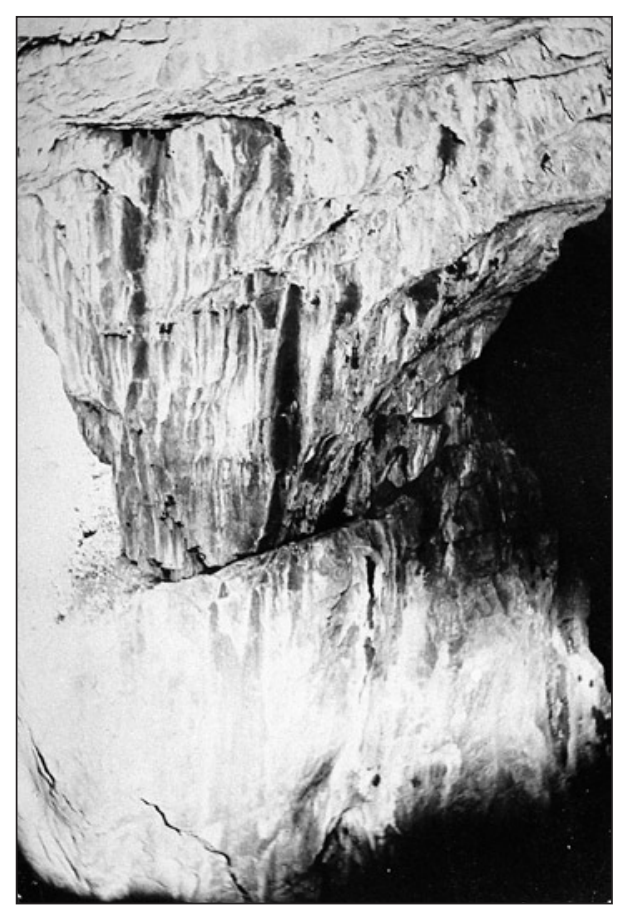

Fig. 19: At the bottom of Okroglica (phot. Benque on f.18). In his album Sigrist-Herder mounted this picture upside-down and mistakenly labelled it "In der Czoernig-Höhle". 
Light would be needed. Silently the delegate of the Schweizer Alpen-Club [Sigrist himself] sat down between the rocks near the path and waited in the darkness until the head of the column had retreated. Then he continued further and was lucky enough to meet two like-minded companions (members of the English and Italian Alpine Clubs) as well as two guides with flares. Immediately they all agreed to penetrate as far as possible into the cave.

With signs and unintelligible words (the people speak the Slovene language) the guides were extremely careful because no pathway would serve us any more, but only hand-wide wooden beams and iron wires secured to the rock for our feet and hands. Since these must be free we left behind us everything we did not need - walking sticks, umbrellas, etc. Soon we were progressing high above the river on a vertical mirror-smooth wall to the Hankejeva dvorana and the Alpenvereinsdom [Dvorana planinskega društva] and further, past fantastic stalactites and thundering waterfalls. It could not be said that this was enjoyable any more, at least not until proper paths have been made. The physical effort bathed us in sweat, the smoke of the flares irritated our eyes and the moving shadows were confusing (Sigrist-Herder 1891).

This extended tour was evidently done only by these three of the many visitors.

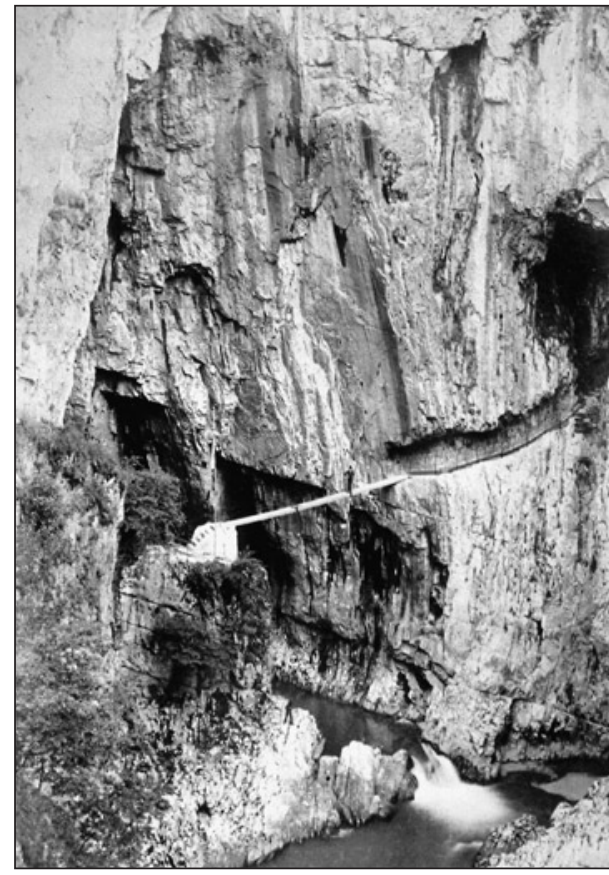

Fig. 20: Brihta jama, on the right, and the very new Konkordija bridge at the entrance of Mariničeva jama in Mala dolina, photographed by Benque in 1891 (f.4v).

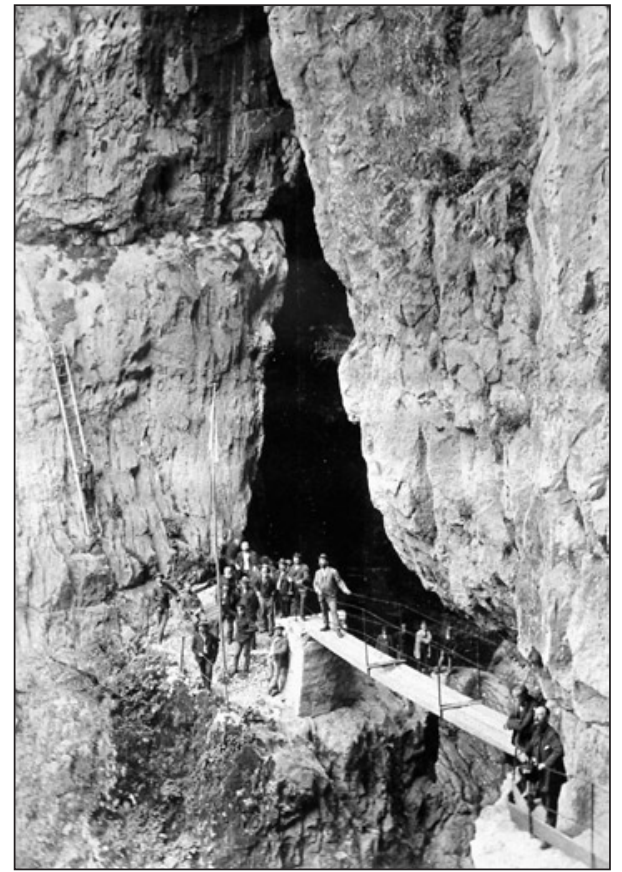

Fig. 21: Konkordija most. This special occasion, with the flag flying, is probably the opening of the newly built bridge on 1 May 1891, or it could have been the excursion of 9 August. (phot. Benque on f.4v). 
As already mentioned The Dvorana planinskega društva (Fig. 10) is about 330 m further downstream than modern tourists now reach at the Hanke bridge (sometimes now called Cerkvenikov most). To put this in perspective, normal tourists in 1891 would be taken to Müllerjeva dvorana, but already "Those who do not object to a rough scramble may penetrate to the eighteenth waterfall" [i.e. Dvorana planinskega društva] according to Baedeker's $(1891,427)$ guidebook. They, like Sigrist, must indeed have been intrepid to have ventured along the narrow plank walks as tourists. A good view of a similar plank walk is provided by Müller (1890, opp. 207) and has often been reproduced since. Such visits are all the more astonishing when it is remembered that that part of the cave had first been reached by the explorers less then four years before, in September 1887 (Pazze 1893, 356). By August 1891 the explorers were already $950 \mathrm{~m}$ beyond that, at Mrtvo jezero, beyond Martelova dvorana.

Sigrist and his two companions who had gone so far were naturally later coming out of the cave than the others. "A glass of wine in the village of Škocjan aroused our somewhat depleted spirits. Then we looked for our colleagues in Matavun where a karst party was being held." The wine they had in Škocjan village itself must have been at the old Deles inn, still open then (Müller 1890, map) and the same place that Schmidl had so disliked forty years earlier (Schmidl 1853, 53). The building is ruined now but the stone seats outside its door can still be seen.

The party at Gombač's inn at Matavun will be described shortly, but it is convenient at this point to note that Sigrist also went into Mahorčičeva jama and perhaps right through Mariničeva

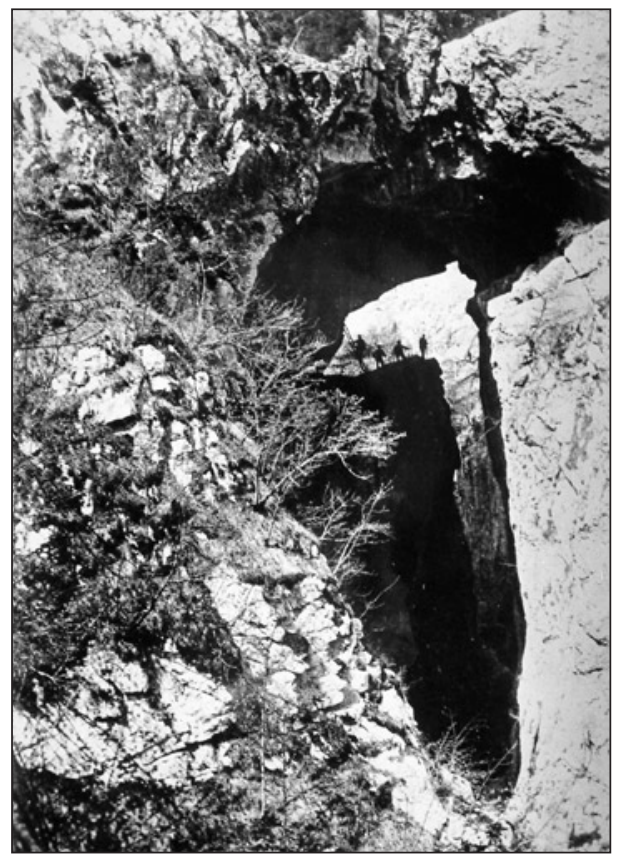

Fig. 22: Looking through beneath Naravni most from Mala dolina showing 4 people silhouetted on Miklov skedenj (phot. Benque on f.18).

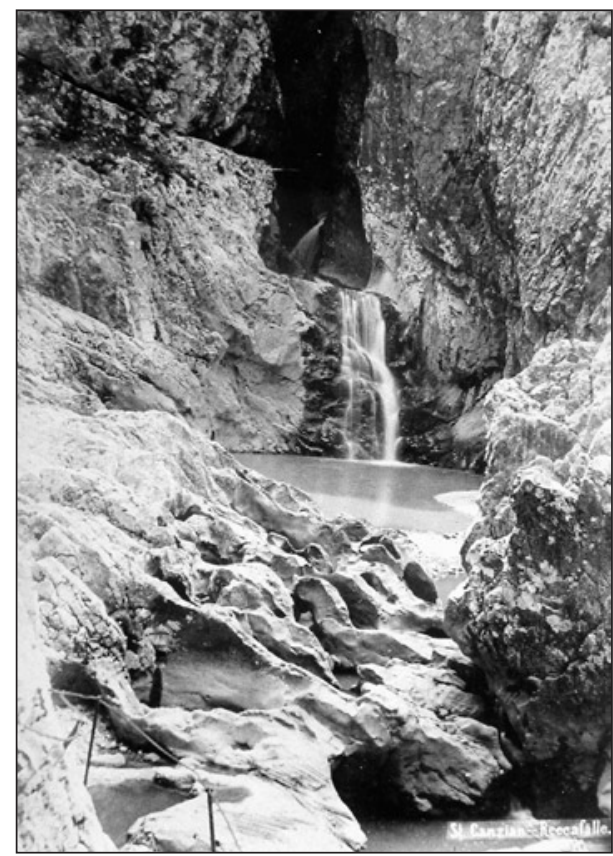

Fig. 23: The Reka entering Velika dolina as the lower waterfall beneath Naravni most (phot. Benque on $f .8 v$ ). 
jama to Mala dolina;

Later I visited also the tunnels that pass beneath the village of Škocjan - the Okroglica, the Mahorčič cave and the Czoernig passage, with magnificent effects of [day]light but not accessible to everybody. The never-tiring men of the karst marvels will surely find ways and means to develop them but will need strong financial support from their friends.

At that time Sigrist would have entered Mahorčičeva jama down the slope through the Okno (Fig. 18). The route through Mahorčičeva jama was made part of the normal tourist way from a little before 1926 until the middle of the 1960s but now it is again, as in Sigrist's time, "not accessible to everybody".

The main cave visit lasted for two hours and, with Sigrist's continuation along the plank walk, must have taken him significantly longer. A group lunch had been arranged at Gombač's inn, specially decorated for the occasion (Fig. 12). As Globočnik-Sorodolski (1891) wrote about "the meals at the small restaurant of Gombač in Matavun. Large establishments might not have succeeded in satisfying such an invasion and that at reasonable prices." Among the toasts was one by "Herr Pazze to the respresentative of the Schweizer Alpen-Club, Herr Sigrist-Herder of Zürich who delivered a spirited poetical greeting [in reply]. Dr Strauss from Konstanz raised his glass to the good health of Baron Carl Czoernig, the founder of the Section Küstenland [in 1873]" (Pazze 1893, 319). Baron Czoernig (Fig. 13) was the father of the nowadays better-known cave explorer Walter Czoernig-Czernhausen of Salzburg (1883-1945) (Angermayer 1950, 34).

After the meal we went to the local peoples' festivities which presented a true impression of

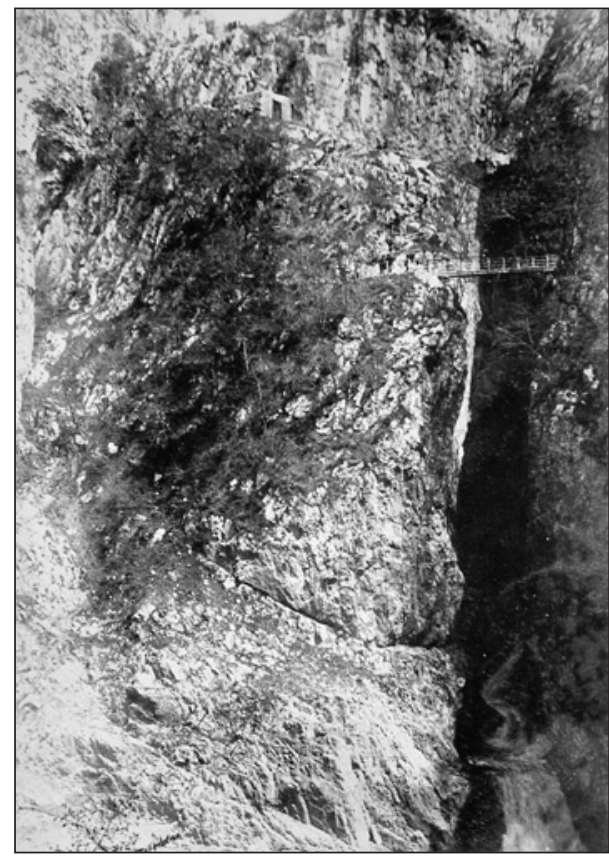

Fig. 24: The Tommasini bridge at the side of Navavni most (phot. Benque on f.4).

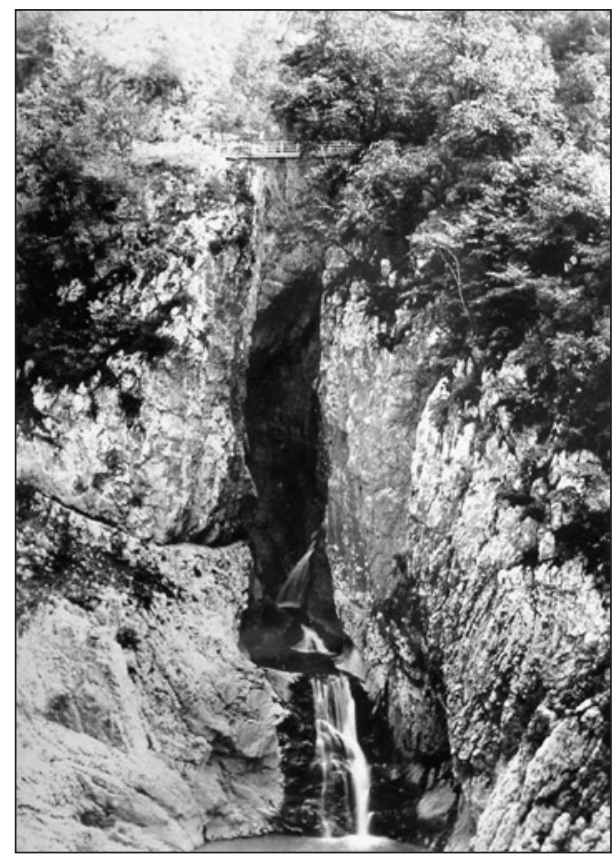

Fig. 25: The Tommasini bridge (phot. Benque on f.6). 
life in the karst and made a pleasant afternoon. Pictures of this were made and offered to interested members as a memento of Škocjan. (Globočnik-Sorodolski 1891)

These afternoon festivities took place in the field with the large doline in it (Figs. 14 \& 15) on the opposite side of the road from the inn. There were dance floors, presumably a band, souvenir kiosks and plenty of drink. A planned balloon ascent was prevented by the high winds. Fig. 14 shows some of the spectators. About 260 people can be counted in that picture alone, so the stated total of 700 (or 300) is not unrealistic and the problems of the cave visit and the lunch can be imagined.

\section{A SIMILAR EXCURSION IN 1885}

A brief comparison between the 1891 visit and one which took place in 1885 shows considerable similarities and some significant differences between the two.

The 1885 excursion followed a DÖAV Annual General Meeting in Villach. Only 90 visitors attended, arriving at Trieste on August 21 and visiting the city and Miramar the next day. On Sunday August 23 there was a Grottenfest at Škocjanske jame. The party set off down Velika dolina at 1100 but as

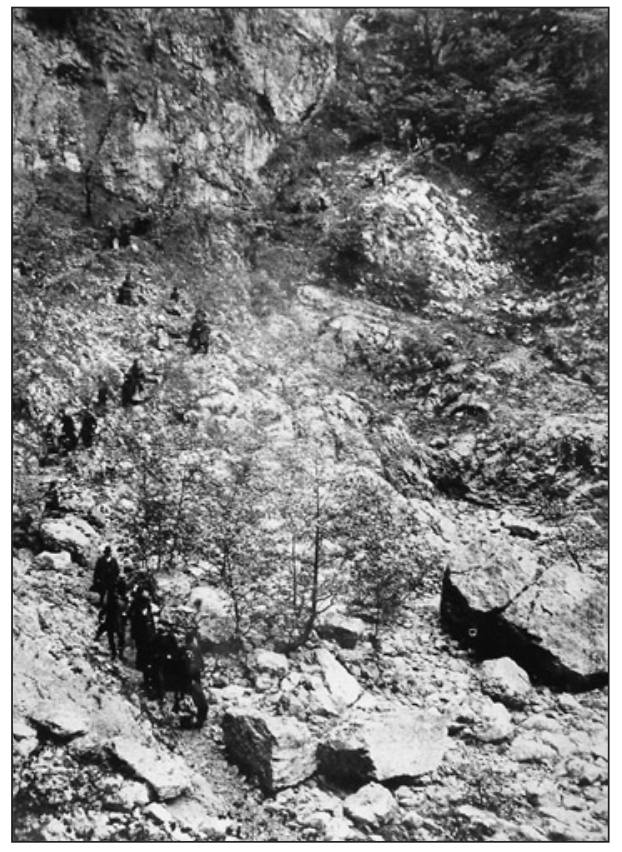

Fig. 26: Near the bottom of Velika dolina, looking just east of north towards Tominčeva jama. The very large boulder on the right is still prominent today. The party may have been on the 1885 excursion or the 1891 one or at some other Grottenfest (see text) (phot. Benque on $f .18 v$, where it is mislabelled "Okroglica").

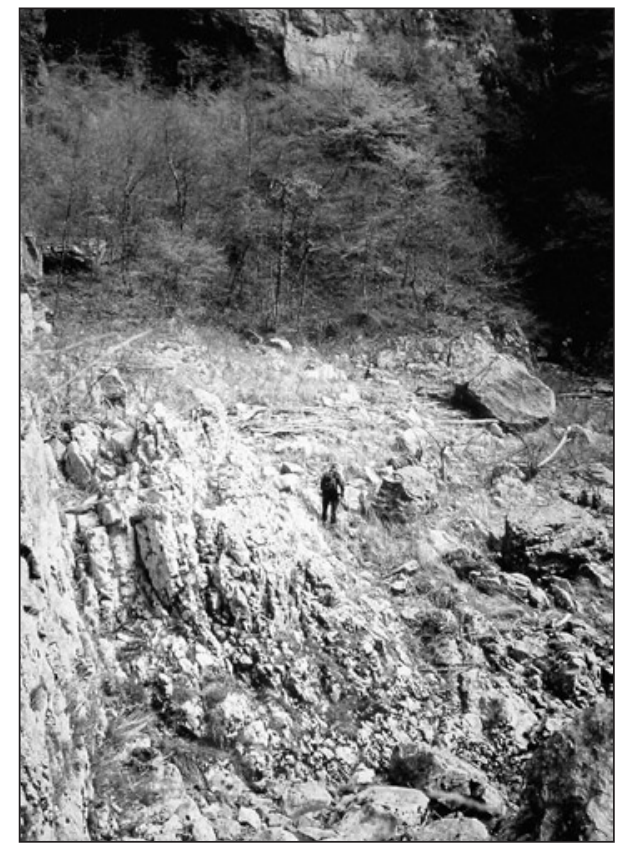

Fig. 27: A similar view to that in Fig. 26, taken from a little further back and showing the same prominent giant boulder (phot. Borut Lozej on 19 April 2002). 


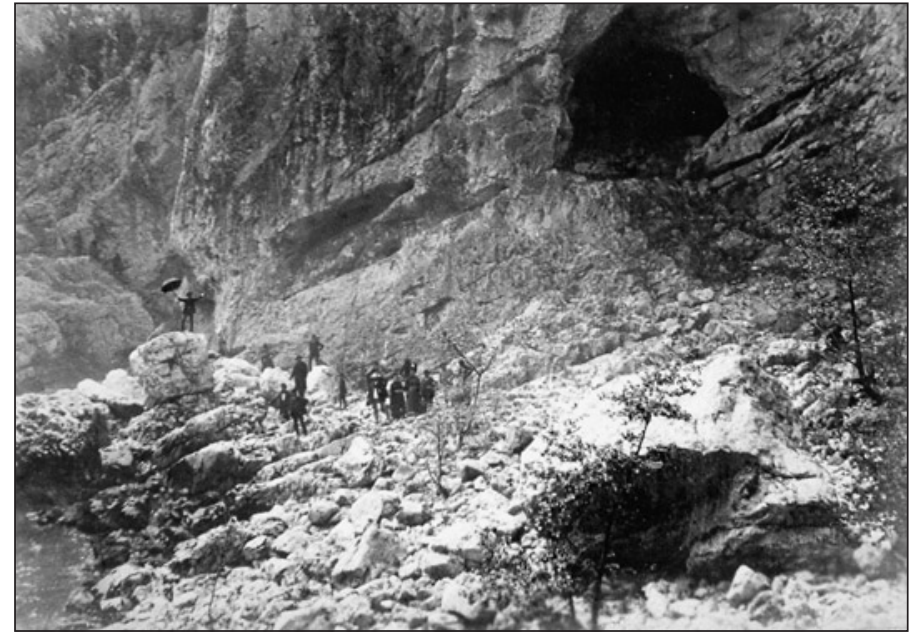

Fig. 28: Near the bottom of Velika dolina, looking south-west towards the hidden Reka sink. These people too, may have been on the excursion of 1885 or 1891 (phot. Benque on f.12).

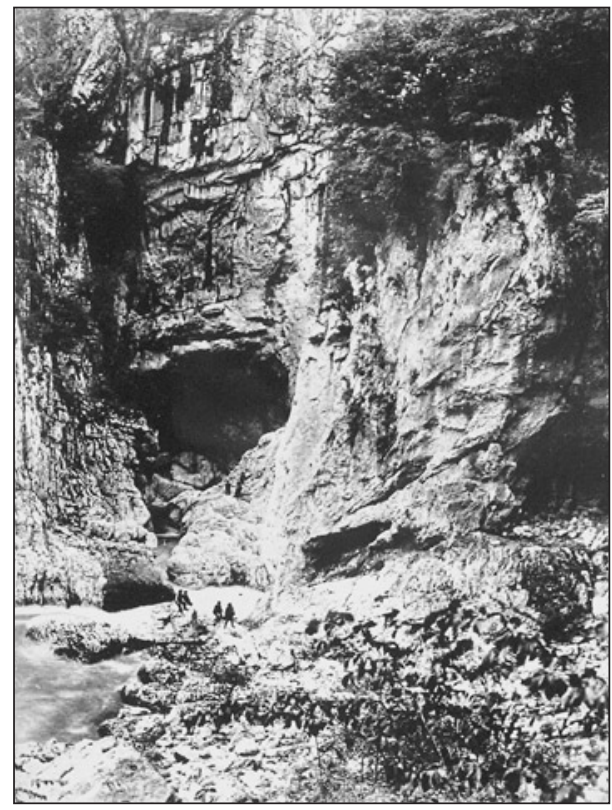

Fig. 29: Approaching the Reka sink in Velika dolina. Photographed by Benque not later than 1887 for it was published by Müller (1887, opp. 64) (on f.10). the direct path (Fig. 33) from Tominčeva jama to Schmidlova dvorana was not cut until 1888 , they had to follow the lower path seen in Fig. 3 and climb up the slope (Fig. 34) to the latter.

The visitors climbed carefully up towards the monumental Schmidl cave where they were greeted by music. They seemed odd, these musical sounds in the underground hall... Hardly had we taken our seats on the many benches to drink beer which was available even down there, when two unusual characters appeared out of the dark depths, both tall but one enormous, far exceeding human size. They were dressed in raincoats; white beards flowed over their breasts; one had a grey hood, the other one wore a gold-trimmed cap. With measured steps they entered the dim space. One of them held a flare high in his hand while the second, steadied by a mighty fallen tree trunk, climbed on to a rock whence he greeted the group as the Enzian King. Dr Radl wrote this greeting... A visit was made to the illuminated Rudolfova dvorana. Standing at the edge of the rushing waters, with a little daylight coming along the passage from the river sink, one could gain some understanding of the difficulties that had been encountered by the explorers. Pale light from magnesium flares shone along the walls and lit up the imposing speleothems. The steep path down to the underground harbour was constructed so carefully that even the most anxious of the ladies present declared that she felt no fear. Indeed most of the pretty ladies and girls proved to be courageous climbers. Atten- 
tion was called to the boats, like bakers' kneading troughs, in which the brave explorers follow the course of the Reka, and which were now safely stored at an adequate height above the river.

At about 1300 the expedition ended and we visited the two inns where hunger and thirst were satisfied. Dancing began in the afternoon on two specially erected floors and lasted late into the evening. ... A small group of enterprising visitors also went into the magnificent Mahorčičeva jama which is more difficult to explore. Afterwards several of the party organized games, such as sack races and pot banging, for the village children and so gained the hearts of the local people. (Pazze 1893, 197-200)

So, the music in Schmidlova dvorana and the appearance of the Enzian King with his poem were the same in both 1885 and 1891, although a king's attendant was mentioned only on the first occasion. The 1885 visitors, however, were taken only as far as Rudolfova dvorana where the path down from Schmidlova dvorana reaches the underground river. This was as far as normal tourist could be taken at that time. Indeed it was only one week earlier, on 15 August, that the explorers themselves had descended the $8^{\text {th }}, 9^{\text {th }}$ and $10^{\text {th }}$ waterfalls and reached the calmer water in Müllerjeva dvorana (Fig. 10) (Puc 1998, 77). The DÖAV explorations in the cave had began only the year before.

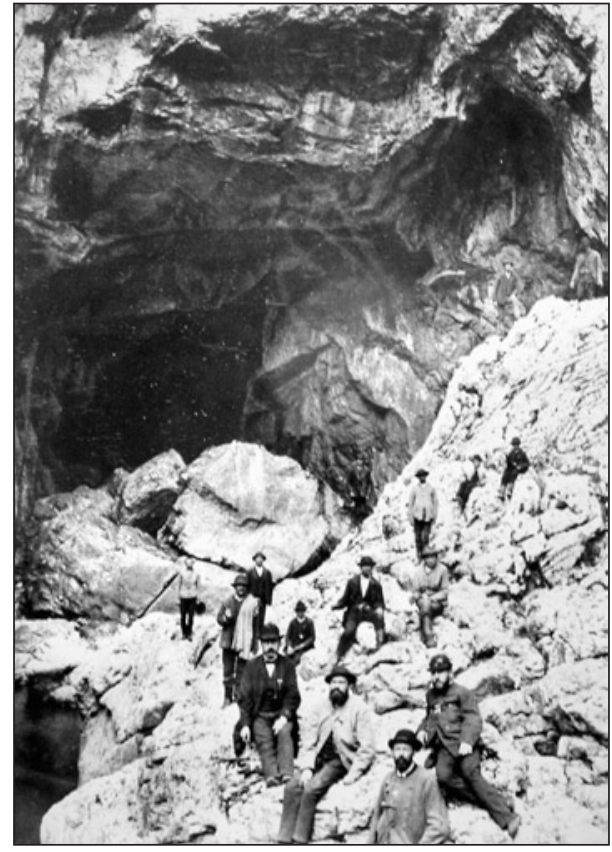

Fig. 30: Close to the Reka sink in Velika dolina. Onf.10 of the album, this photograph is titled in ink "Die Grotten-Pioniere" (the cave explorers). (phot. Benque).

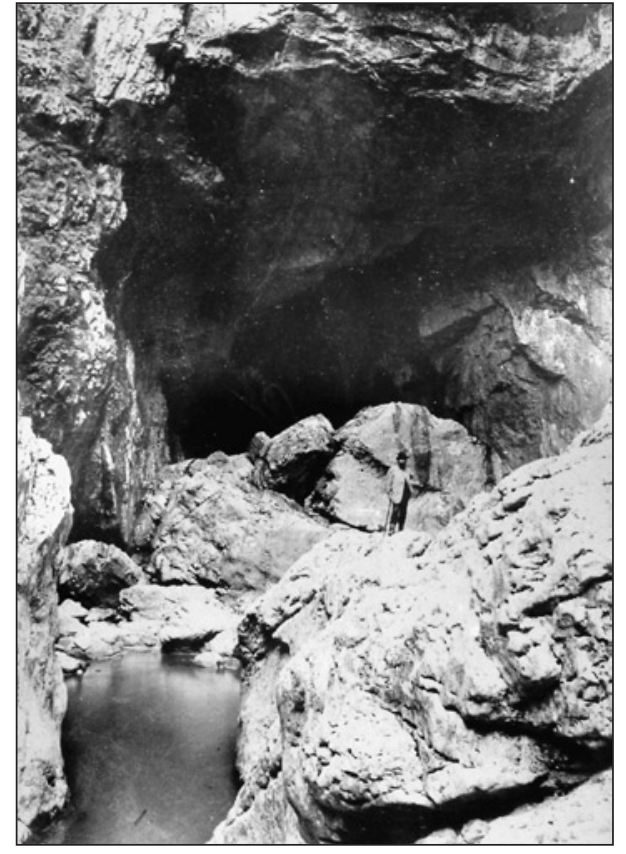

Fig. 31: The Reka sinking in the entrance to the main cave. The ink title on f.18v is "Eingang $z$. Rudolfsdom”. (phot. Benque on f.18v). 


\section{THE PHOTOGRAPHS}

As already mentioned, nineteen of the contemporary photographs mounted in this album of 1891 are reproduced here. Fifteen of these, it is thought, have never been published before; the remaining four were printed once without being attributed to Benque, but have apparently not been published again in the last 111 years. One (Fig. 29) was printed anonymously in Müller (1887, opp. 64) and Figs. 18, 20 and 33, also without naming the photographer, in Kraus's (1894, 253-255) Höhlenkunde where they are only of small size.

At least three of the photographs (Figs. 11, 12 \& 14) are known to have been taken in the course of the excursion visit and have already been referred to in the text. The purpose of this section is to introduce the remaining sixteen pictures which show scenes in and around the Škocjan doline, and also one other such photograph (Fig. 32) belonging to Janko Gombač of Matavun. The latter was another of the Benque pictures to have been printed without acknowledgement by Kraus $(1894,254)$.

The photographer Francesco Benque (1841-1921) was born at Mecklenburg in Germany where he was baptized as Franz. In 1864 he moved to Trieste and opened a photographic studio which continued until 1901, for much of the time under the name Sebastianutti \& Benque (Radacich 2002, 3-8), who were photographers by imperial appointment to the Austrian Court. He became a member

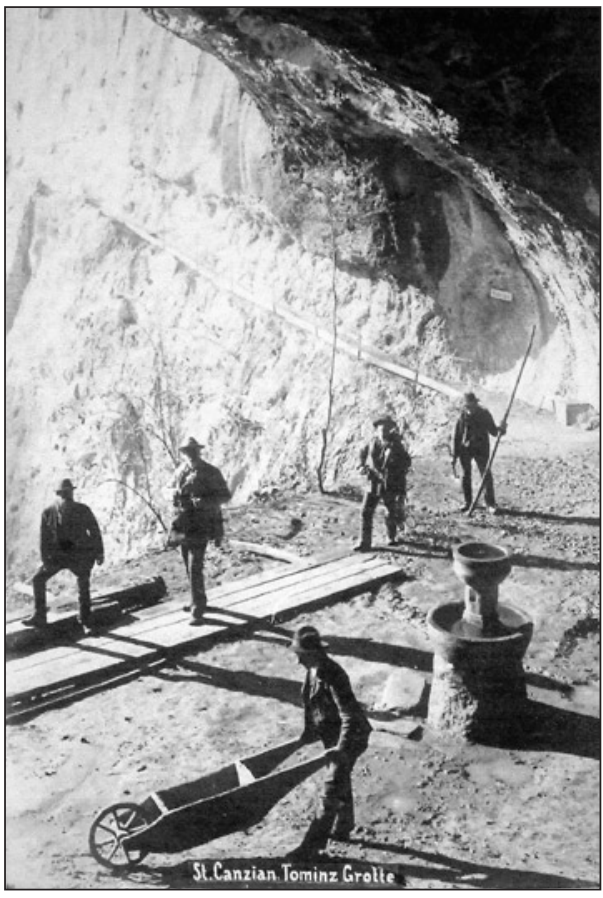

Fig. 32: The entrance of Tominčeva jama during the archaeological excavations. Photographed by Benque between 1889 and 1894. Reproduced with permission, from an original belonging to Janko Gombač of Matavun. of the DÖAV Küstenland Section in 1885 .

Of the 1891 excursion, Globočnik-Sorodolski $(1891,235)$ states that "The court photographers Sebastianutti \& Benque of Trieste have made a number of excellent pictures of the festivities as well as of the descent and the greeting by the cave ghost [Enzian]". This seems to imply that some of the other photographs, not of Enzian or the festivities, were taken on the same day.

Certainly not all can be of that time, for at least one (Fig. 29) had been published already four years before (Müller (1887, opp. 64). So all the others, too, must be considered individually. Many of these other pictures contain no people at all, as would be expected if they were taken then; only Figs 21, 22, 26, 28, $30 \& 33$ have more than three people in them. Six of the pictures around Mahorčičeva jama are not on the route taken by the excursionists, although Sigrist did later go there himself.

Two matters are of particular interest: to identify which photographs were or might have been taken during the 1891 excursion visit; and to provide any available evidence to help date the others. The pictures to be examined to see whether or not they were taken on the day are those in Figs. 21, 22, 26, 28, 30 and 33. 
Fig. 30 is labelled "Die Grotten-Pioniere" by Sigrist in the album and shows 15 people near the Reka sink at the bottom of Velika dolina. The men in this picture do indeed look more like explorers than excursionists. The front four, comparatively well dressed for the photograph, appear to be the DÖAV leading explorers, with the nine behind being the more local cave workers and guides. This scene is not on the main route of the excursion, though some of the visitors could have gone there if they wished.

Fig. 33, showing the Plenkersteig path of 1888 near Tominčeva jama was certainly on the 1891 route, but the two (or three) children with the men are not typical of the excursionists, and children are perhaps unlikely to have been there at all.

The four people on Miklov skedenj (Fig. 22) are on the excursion route, but the man on the ladder suggests a more posed photograph.

The twenty or so men on the bridge (Fig. 21) at the Mariničeva jama entrance near Brihta jama, to which the visitors did go, are dressed in a manner consistent with their being excursionists. But the picture cold equally well show the opening of the newly built bridge earlier in the year (see below).

So, in summary, of the photographs considered so far: one is known to have been made at least four years before; six of the others have very few or no people visible; one appears to feature

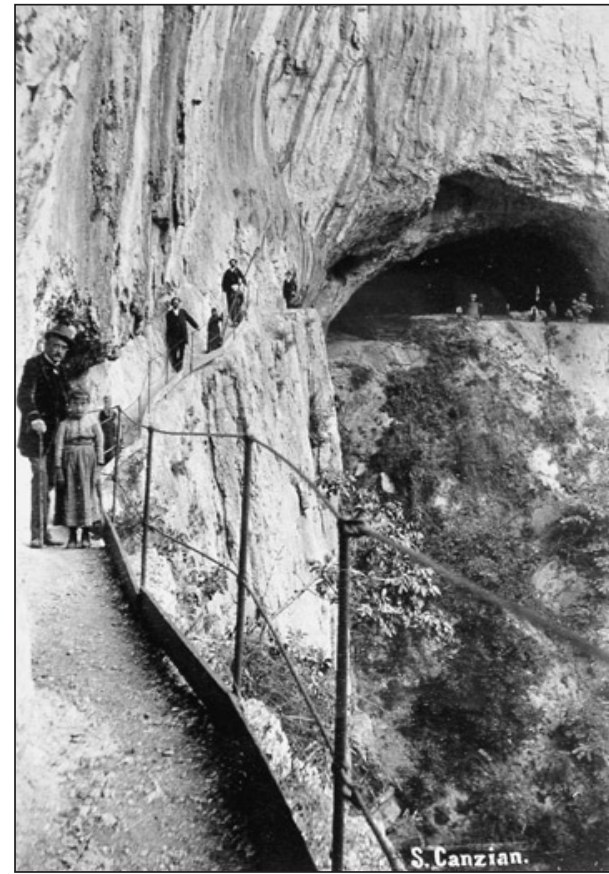

Fig. 33: The Plenkersteig path made in 1888 to provide a direct and level route from Tominčeva jama (in the background) to Schmidlova dvorana. Photographed by Benque in or after 1889. (on f.8v).

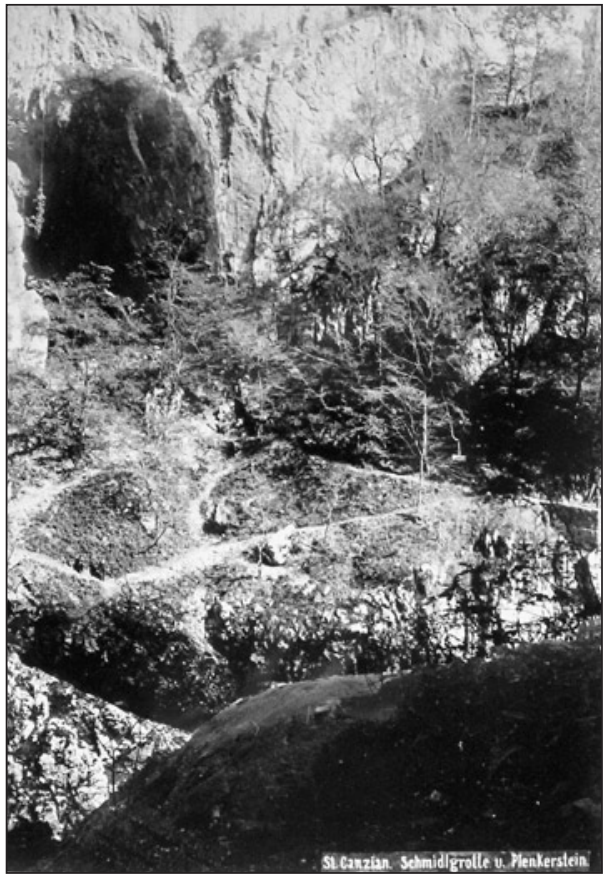

Fig. 34: Schmidlova dvorana and the zig-zag path that provided the normal route to it until 1888. On the right-hand side is the Plenkerstein viewpoint, now an almost unrecognizable ruin. (phot. Benque on f.10v). 
explorers only and also is not on the visitors' route; one has a disproportion of children; one, with only four people on it, looks posed; and one, on the bridge near Brihta jama might or might not be an excursion group.

Two other pictures (Figs. $26 \& 28$ ) show evident groups of visitors. They both include some ladies and in Fig. 28 the man with the umbrella looks more like a cheerful visitor than an explorer. However both pictures deserve further consideration because they are not on the stated route of the 1891 party, which went from Tominčeva jama to Schmidlova dvorana by the path cut in the side of the cliff in 1888 - the Plenkersteig. It is possible that some people might have preferred to go down to the river level, either instead of entering the cave or while the first few hundred people were doing so.

There is also another possibility. Might the people in these pictures have been the excursionists of 1885 who had to follow this lower route and zig-zag up the path shown in Fig. 34 to reach Schmidlova dvorana? In those days there was no Plenkersteig path to take them there directly from Tominčeva jama at the same level. Benque had become a member of the Küstenland section in 1885 and undoubtedly he would have taken photographs during the excursion of that year. Or the photograph could have been taken during some other Grottenfest, such as the one on 10 May 1888 (Pazze 1893, 268-273).

If it is admitted that most of the photographs were not taken during the visit in August 1891, they might have been made at any earlier time and kept ready for sale on such occasions. Any evidence of date, or limitations on possible dates (e.g. by a year of construction) would be helpful.

The bridge Konkordija most in Figs. 20 and 21 was built by May 1891 (Puc 1998, 78) and Fig. 21 might reasonably show the opening ceremony on 1 May; the flag is flying in both pictures so Fig. 20 was probably made on the same day, whether that be 1 May or 9 August.

Fig. 33 of the Plenkersteig path was necessarily after the erection of the Kraus Brunnen basin on its pedestal at the entrance of Tominčeva jama in 1889 .

The excavations in Tominčeva jama (Fig. 32) lasted from 1886 to 1902 (Puc 1998, 77) but the presence of the Kraus Brunnen in the photograph shows that it cannot be earlier than 1889 .

As ready mentioned, Fig. 29 dates from 1887 or before.

The Tommasini bridge in Figs. 24 and 25 was completed in July 1885, so the pictures must be later than that.

The rest of the photographs could have been made any time between 1884, when the DÖAV started work at Škocjan, and August 1891.

\section{ACKNOWLEDGEMENTS}

There are two people without whom this paper could never have been written. Ray Mansfield of Downhead (England) drew my attention to Sigrist-Herder's book being offered for sale in Basel. Rudy Reinbacher of Palo Alto (California) translated long extracts from the German sources used and quoted here. I am also specially grateful to Janko Gombač of Matavun for allowing me to reproduce an original Benque photograph in his possession.

Other help of great importance has been provided by Franjo Drole and Maja Kranjc of the Karst Research Institute ZRC SAZU, Katrina Fletcher of Bath, Pino Guidi of the Società Alpina delle Giulie Commissione Grotte Eugenio Boegan, Dr Philipp Häuselmann of the Universität für Bodenkultur 
in Wien, Dr Monika Kropej of the Institute of Slovenian Ethnology ZRC SAZU, Borut Peric of Park Škocjanske jame, Maurizio Radacich of Trieste, René Scherrer of Hettlingen (Switzerland) and Christine Ballinger of Shoscombe (England).

\section{REFERENCES}

Angermayer, E., 1950 : Dem Andenken eines grossen Höhlenforschers - Gedenkblatt für Ing. Walter Freiherr von Czoernig-Czernhausen.-Die Höhle 1 (3), 33-44, Wien.

Anon., 1891 : Protokoll der XVIII. Generalversammlung des D. u. Oe.

Alpenvereins zu Graz am 5. August 1891. - Mittheilungen des Deutschen und Oesterreichischen Alpenvereins (18), 30 September, [237]-243, Wien.

Anon., 1904 : † Pietro Augusto Pazze. - Il Tourista bollettino del “Club Touristi Triestini” 10 (1-4) gennaio-decembre 1903, 109, Trieste.

Anon., 1910 : Totenliste [J.Sigrist-Herder]. - Alpina Mitteilungen des Schweizer Alpen-Club 18 (6), 15 März, 72, Zürich.

Baedeker, K., 1891 : The eastern Alps, including ... Carniola. Handbook for Travellers $-7^{\text {th }}$ edn. K. Baedeker, xxii, 504 pp; Leipzig.

Balázs, D., 1992 : Some outstanding persons of the speleological and karstological research in the Alps, Carpathian, and Dinaric regions before 1914. - Karszt és Barlang, special issue, 125-129, Budapest.

Debrunner, W., 2002 : letter to René Scherrer dated 12 October.

G[lobočnik-Sorodolski], V., 1891 : Generalversammlung. Ausflug an die Adria und nach St. Canzian. - Mittheilungen des Deutschen und Oesterreichischen Alpenvereins (17), 15 September, 234-235. Wien.

Kraus, F., 1894 : Höhlenkunde ... - C. Gerold's Sohn, [vii], 308 pp., Wien. Müller, F., 1887 : Führer in die Grotten und Höhlen von Sanct Canzian bei Triest und Notizen über den Lauf der Reka. - Deutscher und Österreichischer Alpenverein. Section Küstenland, 111 pp., Triest.

Müller, F., 1890 : Die Grottenwelt von St. Canzian. - Zeitschrift des Deutschen und Oesterreichischen Alpenvereins 21, 193-251, Wien.

Müller, F., 1891 : Entdeckungsfahrten in den St. Canzianer Höhlen im Jahre 1890 vom 18. bis 25. unterirdischen Wasserfall. - Mittheilungen des Deutschen und Oesterreichischen Alpenvereins (8), 30 April,, [99]-103; (9), 15 Mai, [115]-118; (10), 31 May, 129-131, Wien.

Müller, F., 1916 : Personalnachrichten. Josef Marinitsch †. - Mitteilungen des Deutschen und Österreichischen Alpenvereins, (7 \& 8), 30 April, 67-8, München \& Wien.

Pazze, P.A., 1893 : Chronik der Section Küstenland des Deutschen und Österreichischen Alpenvereins, 1873-1892. - Section Küstenland, [iii], 372 pp., Triest.

Puc. M., 1998 : Pomembnejši datumi v raziskovanju in turistični ureditvi Škocjanskih jam. - Naše jame 40, 75-80, Ljubljana.

Radacich, M., 2002 : Le Grotte di San Canziano nelle fotografie di Francesco Benque - Club Alpinistico Triestino - Gruppo Grotte, 31 pp., Trieste.

Rudaux, L., 1910 [Die grosse Doline von der Stephanienwarte aus.] -Jahresbericht der Sektion Küstenland des Deutschen und Oesterreichischen Alpenvereins für das Jahr 1909, back cover, Triest. 
Scherrer, R., 2005 : letter to Trevor Shaw dated 27 February.

Schmidl, A., 1853 : Wegweiser in die Adelsberger Grotte und die benachbarten Höhlen des Karst... - W. Braumüller, xvi, 88 pp., Wien.

Sigrist [-Herder, J], 1891 : Die Grottenwelt von St. Canzian und der unterirdische Flusslauf der Reka bei Triest. - Neue Zurcher Zeitung 71, (336) 2 Dec.; (338) 4 Dec.; (339) 5 Dec., Zürich.

[Sigrist -Herder, J.], 1893 : Vom Clubfeste in St. Gallen. Busspredigt des Kapuzinerpaters Kobi ...- Alpina Mitteilungen des Schweizer Alpen-Club 1 (3), 1 Sept., 32, Zürich. 